\title{
Analisis Pelaksanaan Pencatatan Petty Cash (Kas Kecil) Pada PT MNI Entertainment Jakarta Pusat
}

\author{
Eulin Karlina $^{1}$, Fajri Ariandi ${ }^{2}$, Siti Dedeh Humaeroh ${ }^{3}$, Rini Martiwi ${ }^{4}$ \\ 1,2,3,4 Universitas Bina Sarana Informatika \\ e-mail: ${ }^{2}$ eulin.eka@bsi.ac.id \\ ${ }^{2}$ fajri.fdi@bsi.ac.id \\ ${ }^{3}$ sitidede2703@gmail.com \\ 4rini.ntw@bsi.ac.id
}

\begin{tabular}{ccc} 
Diterima & Direvisi & Disetujui \\
$26-08-2019$ & $18-09-2019$ & $24-09-2019$ \\
\hline
\end{tabular}

\begin{abstract}
Abstrak - Setiap perusahaan pasti dibentuk bagian kas, dan bagian kas akan dibantu bagian petty cash yang ditandatangani oleh petugas pelaksanaan petty cash dan fungsi-fungsi bersangkutan untuk membantu kinerja operasional secara langsung. transaksi yang terjadi tidak begitu rumit, namun harus melakukan pengelolaan secara baik dan teliti berdasarkan prosedur operasi pelaksanaan perusahaan yang ada. Untuk itulah penulis mencoba membuat Tugas Akhir mengenai pelaksanaan pencatatan petty cash (kas kecil) pada PT MNI Entertainment Jakarta Pusat. Adapun metode yang digunakan dalam penelitian ini yaitu menggunakan metode deskriptif kualitatif dengan teknik pengumpulan data melalui observasi, wawancara dan dokumentasi. Pelaksanaan pencatatan petty cash pada PT MNI Entertainment Jakarta Pusat yaitu dengan menggunakan metode imperst, yang mana dalam metode ini penetapan jumlah dana kas kecil selalu tetap dalam periodenya. Dalam pelaksanaan petty cash ini terdapat prosedur pelaksanaan dan beberapa pencatatan yang diterapkan untuk melakukan kegiatan operasionalnya seperti pembentukan dana kas kecil, dan pengisian kembali dana kas kecil.
\end{abstract}

\section{Kata Kunci : Pencatatan, Petty Cash}

\begin{abstract}
Each company must have a cash section formed, and the cash portion will be assisted by a petty cash section signed by the petty cash implementation officer and related functions to assist operational performance directly. transactions that occur are not very complicated, but must carry out management properly and thoroughly based on the operating procedures of the existing company. For this reason, the author tries to make a final assignment regarding the recording of petty cash at PT MNI Entertainment, Central Jakarta. The method used in this study is to use a qualitative descriptive method with data collection techniques through observation, interviews and documentation. The registration of petty cash at PT MNI Entertainment Central Jakarta is by using the imperst method, which in this method the determination of the amount of petty cash funds is always fixed in the period. In the implementation of the Petty Cash there are implementation procedures and several records that are applied to carry out operational activities such as the establishment of a petty cash fund, and refill petty cash funds.
\end{abstract}

Keywords: Implementasion, Recording, Petty Cash

\section{PENDAHULUAN}

Cash (kas) merupakan komponen penting dalam siklus operasional suatu perusahaan. Setiap perusahaan pasti dibentuk bagian kas, dan bagian kas akan dibantu bagian petty cash ( kas kecil ) yang ditanda tangani oleh petugas pelaksanaan petty cash dan fungsi-fungsi bersangkutan untuk membantu kinerja operasional langsung. Transaksi yang terjadi tidak begitu rumit namun harus melakukan pengelolaan secara baik dan teliti berdasarkan prosedur operasi pelaksanaan dana perusahaan yang ada. Pengelolaan dana kas kecil yang tidak memadai atau cenderung buruk dapat mengganggu kelancaran operasional perusahaan.

Nilai petty cash memiliki peranan yang penting dalam operasional perusahaan untuk itu, perusahaan hendaklah melakukan pengelolaan petty cash secara baik. pelaksanaan petty cash mutlak diperlukan, Tidak ada alasan bagi perusahaan untuk tidak melakukan pengelolaan. Kas atau petty cash sering digunakan untuk membiayai keperluan organisasi yang sifatnya kecil atau sehari-hari. Namun, pengeluaran kecil atau sehari-hari tersebut sering terjadi sehigga jumlah totalnya menjadi cukup besar. Oleh karena itu, pengeluaran semacam ini 
perlu di kendalikan. Jadi organisasi perlu membentuk suatu dana khusus yang disebut kas kecil atau petty cash.

Kas kecil merupakan dana khusus yang dibentuk organisasi untuk membiayai pengeluaran organisasi yang sifatnya kecil atau sehari-hari. Dana kas kecil (petty cash) dibentuk berdasarkan perkiraan pengeluaran biaya operasional perusahaan, Contohnya biaya yang dikeluarkan untuk membayar tekening listrik, telepon, trasportasi, biaya keamanan dan biaya-biaya lainnya. Selain untuk membayar pengeluaran-pengeluaran perusahaan yang jumlah nominalnya kecil, pembentukan petty cash juga bertujuan untuk membayar pengeluaran yang sifatnya mendadak dan sebagai dana langsung untuk jenisjenis pembayaran yang tidak praktis apabila menggunakan cek.

Setiap perusahaan memiliki kas kecil sebagai cadangan uang untuk mendukung kegiatan operasional kantor. Oleh karena itu, kantor perlu menunjuk staf yang berwenang untuk mengelola kas kecil dalam fungsinya guna membiayai seluruh pengeluaran yang bersifat kecil maupun transaksi keuangan bagi kepentingan kantor.

Kas biasanya digunakan untuk menggambarkan kepemilikan uang suatu perusahaan. Semakin besar nilai kas sebuah perusahaan, maka semakin besar pula uang yang mereka miliki. Kas dibutuhkan suatu perusahaan baik digunakan untuk membiayai operasi perusahaan sehari-hari maupun pembelian aktiva tetap atau rutin.

Menurut Yandi dalam (Hidayati, 2019) mengemukakan bahwa "kas merupakan komponen penting dalam jalannya kegiatan-kegiatan operasional perusahaan".

Sedangkan menurut Supriyati dalam (Arizona, Yulia, \& Saputro, 2018) mengatakan bahwa "kas adalah uang yang disimpan diperusahaan atau bank yang setiap saat bisa diuangkan tanpa mengurangi nilainya".

Adapun menurut Prianthara dalam (Wasiyanti, 2015) mengemukakan bahwa "kas terdiri dari uang kertas, uang logam, dan simpanan di bank dalam bentuk rekening giro (demand deposit atau checking account)".

Sedangkan menurut (Lubis \& Dewi, 2017) menyatakan bahwa "kas adalah aktiva lancar yang meliputi uang kertas atau logam dan benda-benda lain yang dapat digunakan sebagai media tukar atau alat pembayaran sah dan dapat diambil setiap saat.

Berdasarkan definisi tersebut dapat disimpulkan bahwa kas merupakan komponen penting suatu perusahaan yang terdiri dari uang kertas, logam dan benda-benda lain yang dapat digunakan sebagai media tukar atau pembayaran yang sah dan dapat diambil setiap saat tanpa mengurangi nilainya.

Setiap perusahaan memiliki kas kecil sebagai cadangan uang untuk mendukung kegiatan operasional kantor. Oleh karena itu, kantor perlu menunjuk staf yang berwenang untuk mengelola kas kecil guna membiayai seluruh pengeluaran yang bersifat "kecil" maupun transaksi keuangan bagi kepentingan kantor. Sejumlah uang yang telah digunakan harus dikembalikan ke kas kecil dengan jumlah yang sama, lebih besar atau lebih kecil dari jumlah yang telah digunakan sehingga alokasi dana yang digunakan dapat dikembalikan ke dana petty cash seperti jumlah semula.

Menurut (Yuniarwati, Santioso, Ekadjaja, \& Rasyid, 2017) mengemukakan bahwa "kas kecil atau yang sering disebut petty cash memiliki pengertian sebagai uang tunai yang disediakan suatu usaha untuk membayar pengeluaran-pengeluaran yang jumlahnya relatif kecil dan tidak ekonomis bila dibayar dengan menggunakan cek/bilyet giro.

Adapun menurut (Erhans, 2016) menyatakan bahwa "kas kecil (petty cash) adalah uang tunai yang disediakan untuk pengeluaran-pengeluaran yang jumlahnya relatif kecil, misalnya membeli alat tulis, membeli materai dan sebagainya.

Sedangkan menurut Ardiyos dalam (Atika \& Pusung, 2018) menyatakan bahwa "kas kecil (petty cash) adalah sejumlah uang tunai atau kas yang disediakan untuk melayani pembayaran keperluan perusahaan yang rutin dan meliputi jumlah yang relatif kecil".

Dari definisi diatas dapat disimpulkan bahwa kas kecil merupakan uang tunai yang disediakan untuk membiayai pengeluaran-pengeluaran perusahaan yang jumlahnya relatif kecil dan rutin sehingga tidak ekonomis jika menggunakan cek.

Dana kas kecil dipercayakan kepada pemegang kas kecil yang bertanggung jawab terhadap pengelolaan dana kas kecil. Menurut (Yuniarwati, Santioso, Ekadjaja, \& Rasyid, 2017) kas kecil memiliki beberapa karakteristik yaitu:

1. Jumlahnya dibatasi tidak lebih atau tidak kurang dari suatu jumlah tertentu yang telah ditentukan oleh manajemen perusahaan. Tentunya masingmasing perusahaan menetapkan jumlah yang berbeda sesuai dengan skala operasional perusahaan.

2. Dipergunakan untuk mendanai transaksi kecil yang sifatnya rutin setiap hari.

Sedangkan menurut (Wati \& Kusumo, 2016)

Karakteristik dasar dari kas kecil adalah:

1. Kas kecil jumlahnya dibatasi, tidak lebih atau tidak kurang dari suatu jumlah tertentu yang telah ditentukan oleh manajemen perusahaan. Besarnya kas kecil tergantung kebijaksanaan masingmasing perusahaan.

2. Kas kecil dipergunakan untuk membiayai dan mendanai pengeluaran-pengeluaran yang sifatnya rutin setiap hari.

3. Kas kecil disimpan ditempat khusus, biasanya dengan menggunakan kotak kecil yang disebut dengan Petty Cash Box. 
Menurut (Samryn, 2015) pengelolaan dana kas kecil meliputi tiga tahapan pekerjaan yang terdiri dari:

1. Pembentukan dana kas kecil

Pembentukan kas kecil harus ditetapkan berdasarkan estimasi kebutuhan dana dalam periode waktu tertentu, misalnya seminggu. Pembentukan dana kas kecil dapat ditetapkan dengan alternatif membentuk dana tetap (imprest fund). Dalam sistem ini plafon dana kas kecil tidak berubah pada setiap kali pengisian. Sistem lain adalah sistem dana berfluktasi (fluctuative fund). Dalam sistem ini pengisian dana kas kecil dapat dilakukan dengan jumlah yang mengubah plafon dana kas kecil.

2. Pemakaian dana kas kecil

Sesuai dengan namanya dana kas kecil digunakan untuk memenuhi pembelanjaan dalam jumlah yang relatif kecil. Misalnya untuk memenuhi pembayaran biaya-biaya kebutuhan kantor, atau kebutuhan pabrik sehari-hari seperti makan siang tamu kantor, pengiriman surat, pembelian air minum pembayaran telpon dan lain sebagainya.

3. Pengisian kembali dana kas kecil

Pengisian dana kas kecil dapat dilakukan sesuai dengan periode yang ditetapkan, misalnya sekali dalam seminggu. Pada saat pengisian kembali, kasir kas kecil menyerahkan bukti-bukti pengeluaran kas, atau catatan lain kepada penanggung jawab keuangan perusahaan. Jumlah penggantian kas kecil yang diminta harus sama dengan nilai uang yang dikeluarkan menurut bukti pengeluaran kasnya.

Menurut (Hermawan, Maryanti, \& Biduri, 2018) ada dua sistem atau metode dalam pembentukan petty cash yaitu imprest fund system dan fluctuating fund system. Untuk tujuan pengendalian perusahaan biasaya akan membatasi jumlah maksimum tertentu dan jenis-jenis pembayaran yang boleh dilakukan atas dana kas kecil. Kebanyakan dana kas kecil dibentuk atas dasar jumlah yang tetap yang dinamakan sebagai sistem dana tetap (Imprest fund system).

\section{METODOLOGI PENELITIAN}

Tujuan dari penelitian ini adalah menganalisis pelaksanaan pencatatan petty cash dan untuk mengetahui metode yang digunakan dalam pengelolaan petty cash serta prosedur pencatatan petty cash pada PT MNI Entertainment Jakarta Pusat

Metode penelitian yang digunakan dalam penelitian ini adalah deskriptif kualitatif dengan metode pengambilan data menggunakan metode observasi yaitu melakukan pengamatan langsung yang berkaitan dengan pencatatan kas kecil pada PT MNI Entertainment Yang berlokasi di Jl. K.H Wahid Hasyim Kav. 28 Jakarta Pusat, metode wawancara yaitu melakukan tanya jawab langsung dengan mengajukan pertanyaan yang berkaitan dengan pencatatan kas kecil, wawancara dilakukan dengan Ibu Ika Setiawati selaku bagian Finance pada PT MNI Entertainment Jakarta Pusat, dam studi dokuemntasi yaitu melakukan pengumpulan data pelengkap dengan cara melampirkan dokumen-dokuemn mengenai pelaksanan pencatatan kas kecil yang dilakukan oleh PT Mni Entertainmen Jakarta Pusat. Dengan periode data yang digunakan adalah bulan Januari samapai dengan bulan Maret 2019

\section{HASIL DAN PEMBAHASAN}

\section{Metode Pengelolaan Petty Cash pada PT MNI Entertainment Jakarta Pusat}

Pengelolaan kas kecil yang diterapkan oleh PT MNI Entertainment yaitu dengan menggunakan metode atau sistem dana tetap (Imperst system), yang mana dalam metode ini penetapan jumlah dana kas kecil selalu tetap dalam periodenya.

PT MNI Entertainment telah menetapkan dana petty cash atau kas kecil sejumlah Rp 9.000.000,untuk satu periode pengeluaran, dana kas kecil tersebut digunakan untuk membiayai kegiatankegiatan operasional perusahaan yang jumlahnya relatif kecil dan bersifat rutin, pengisian kembali dana kas kecil pada PT MNI Entertainment dilakukan setiap akhir periode (setengah bulan) atau pada saat saldo kas kecil telah menipis.

Dana kas kecil yang terdapat pada PT MNI Entertainment Jakarta Pusat adalah dana kas kecil per project, jadi untuk setiap kegiatan operasional perusahaannya memiliki batasan anggaran tersendiri untuk setiap periodenya. Adapun batasan anggaran tersebut adalah sebagai berikut:

1. Peralatan dan perlengkapan kantor

Pengeluaran ini biasanya digunakan untuk pengeluaran kebutuhan kantor sehari-hari seperti, kebutuhan ATK, biaya telepon, pembelian materai, biaya kirim majalah, belanja bulanan dan lain-lain. Untuk batas maksimal pengeluaran ini yaitu tidak melebihi Rp 600.000,--. Untuk setiap transaksi pembayaran pengeluaran.

2. Reimbursement Operasional GA (General Affair) Untuk kegiatan pengeluaran operasional GA dikarenakan pengeluarannya cukup banyak, maka dilakukan sistem reimburse atau penggantian sejumlah uang, dan biasanya pengeluaran akan diakumulasikan oleh pihak GA (General Affair) yang kemudian akan diberikan kepada pihak kasir dalam satu atau dua minggu sekali pembayaran. Dana yang disediakan untuk Reimbursement Operasional GA adalah sebesar Rp 3.000.000,untuk satu kali pengajuan kepada kasir. Pihak GA bisa melakukan lebih dari satu kali reimburse dalam 1 (satu) periodenya, asalkan setiap pengajuan kepada kasirnya tidak melebihi $\mathrm{Rp}$ 3.000.000,-. Contoh dari kegiatan yang tergolong dalam reimbursement operasional GA adalah 
pembayaran parkir kendaraan, bensin, ganti oli, dan lain-lain.

3. Entertaint

Dana yang disediakan untuk kegiatan ini yaitu sebesar Rp. 1.500.000,- dalam satu periode. Jika pengeluaran entertaint dalam satu periodenya melebihi atau kurang dari Rp 1.500.000,-, maka pihak kasir akan memberikan pengeluaran entertaint untuk periode berikutnya. Contoh dari kegiatan ini yaitu seperti pengeluaran jamuan untuk relasi bisnis dan lain-lain.

\section{Prosedur Pencatatan Petty Cash Pada PT MNI Entertainmen Jakarta Pusat}

Secara umum prosedur pencatatan petty cash berfungsi sebagai alat untuk mencapai suatu tujuan tertentu. Dalam pelaksanaannya, proses dari prosedur ini menyangkut pihak-pihak yang terkait dalam pencatatan petty cash yang dilakukan oleh PT MNI Entertainment, cara pengerjaan dan urutan kerja yang berlangsung dalam kegiatan tersebut.

Prosedur pencatatan petty cash yang sudah berjalan pada PT MNI Entertainment Jakarta Pusat dapat dilihat pada gambar prosedur pencatatan petty cash sebagai berikut

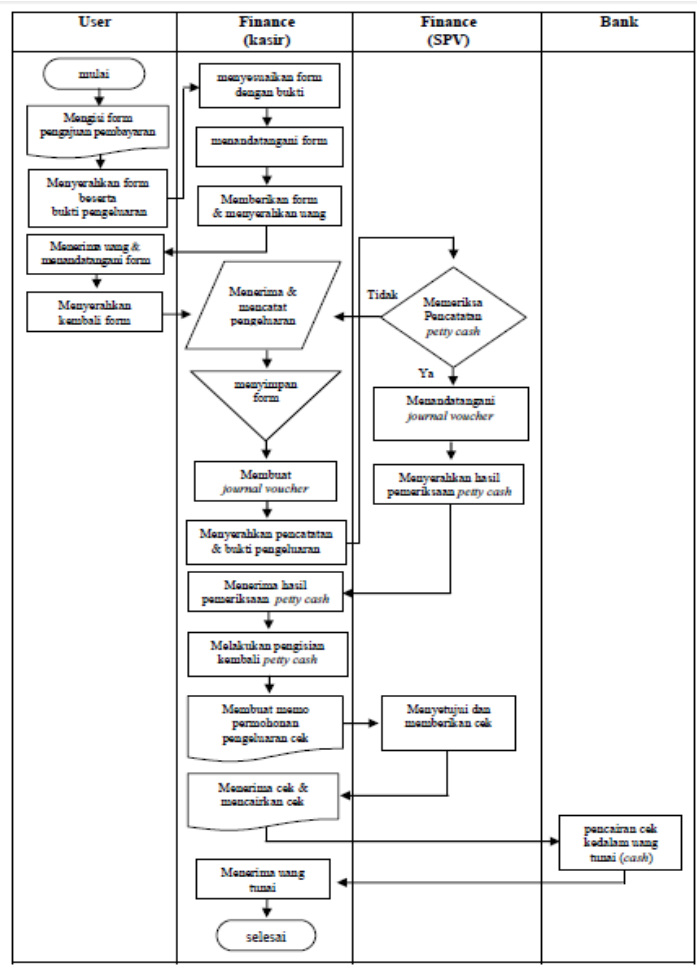

Sumber: Finance PT MNI Entertainmen (2019)

\section{Gambar 1 Prosedur Pelaksanaan Petyy Cash Pt Mni Entertainmen Jakarta Pusat}

Berdasarkan gambar di atas maka penulis menjelaskan prosedur pencatatan petty cash pada PT MNI Entertainment, sebagai berkut:

\section{User}

Hal yang pertama dilakukan untuk mengajukan atau mengeluarkan sejumlah dana kas kecil dari kasir yaitu dengan mengisi form pengajuan pembayaran terlebih dahulu. pihak user mengisi form pengajuan pembayaran kemudian memberikan form pengajuan tersebut beserta bukti pengeluaran petty cash seperti faktur, kwitansi, bon dan lain-lain kepada pihak kasir untuk disesuaikan. Setelah pengeluaran di sesuaikan, user akan menerima uang penggantian sesuai dengan yang tercatat pada form pengajuan kemudian akan menandatangani form pengajuan dana tersebut pada bagian "penerima" yang menyatakan bahwa pihak user sudah menerima penggantian sejumlah uang kas kecil dari kasir kemudian form tersebut dikembalika ke kasir.

2. Finance "kasir"

Bagian kasir menerima pengajuan pembayaran petty cash dan sejumlah bukti pengeluaran dari pihak user, kemudian kasir akan menyesuaikan apakah nominal yang tertera pada form pengajuan sesuai dengan bukti yang dikeluarkan atau faktur yang terlampir, jika sudah sesuai maka kasir akan menandatangani form tersebut pada kolom "kasir" yang menyatakan bahwa pengajuan telah sesuai, kemudian kasir akan menyerahkan sejumlah uang sesuai dengan yang tertulis pada form pengajuan kepada kasir, kasir akan mencatat setap pengeluaran tersebut pada komputer dengan mengisi periode, nomor bukti, nama pengeluaran dan nominal pembayaran, dan kemudian menyimpan bukti pengeluaran tersebut ke dalam summary petty cash.

Jika pengeluaran sudah mencapai akhir periode dan hampir mencapai nominal Rp 9.000.000,Sebelum melakukan pengisian kembali, kasir akan memposting seluruh pengeluaran ke dalam journal voucher yang menandakan bahwa seluruh pengeluaran sudah masuk ke dalam sistem perusahaan. Journal voucher di isi dengan mencantumkan tanggal, nomor bukti, dan keterangan sesuai dengan pencatatan pengeluaran yang telah dilakukan sebelumnya. Petty cash yang sudah diposting akan dilampirkan dan di tandatangani oleh kasir pada bagian "prepared by" dan "posted by". Kemudian seluruh pengeluaran yang sudah masuk ke dalam summary petty cash akan diserahkan pada bagian finance SPV untuk diperiksa pencatatannya.

Setelah disetujui, kasir akan melakukan pengisian kembali petty cash. Untuk melakukan pengisian kembali dana petty cash, kasir akan membuat memo permohonan pengeluaran cek kepada SPV finance. Kemudian kasir akan menerima cek dan mencairkan cek tersebut ke bank dan akan menjadi saldo awal petty cash periode berikutnya.

3. Finance "SPV"

Bagian SPV finance akan menerima dan memeriksa seluruh pencatatan petty cash yang telah diajukan oleh bagian kasir. setelah disetujui, 
SPV finance akan menandatangani journal voucher pada bagian "reviewed by" dan menyerahkan kembali hasil pemeriksaan kepada kasir. Kemudian untuk melakukan pengisian kembali petty cash, SPV Finance akan menerima memo permohonan pengeluaran cek dari kasir, setelah disetujui pihak SPV finance akan mengeluarkan cek dan memberikan cek tersebut kepada kasir.

4. Bank

Bagian bank akan menerima cek dari pihak kasir yang kemudian akan dicairkan kedalam uang tunai (cash) dan setelah uang tersebut dicairkan pihak bank akan menyerahkan uang tersebut kepada pihak kasir.

\section{Pelaksanaan pencatatan Prtty Cash Pada PT MNI Entertainmen Jakarta Pusat}

Dalam pelaksanaan petty cash yang diterapkan oleh PT MNI Entertainment yang pertama kali dilakukan yaitu dengan menyerahkan bukti transaksi pembayaran yang telah dilakukan, bukti transaksi bisa berupa faktur, kwitansi,memo, bon dan lain-lain.

Bagian user akan mengisi form pengajuan pembayaran untuk meminta sejumlah uang kepada kasir senilai yang telah dikeluarkan dalam bukti pembayaran.Form diisi dengan menulis nama keterangan dan nominal. Untuk tanggal dan nomor petty cash kasir akan mencatatnya sesuai dengan tanggal dan nomor pada pengisian journal voucher nanti.

Kemudian setiap transaksi yang diserahkan oleh pihak user kepada kasir akan dicatat oleh bagian kasir dengan mengisi nama periode, nomor bukti, nama keterangan dan nominal. Setelah mencatat semua transaksi pengeluaran, pencatatan terakhir yaitu dengan memposting pengeluaran kedalam journal voucher. Berikut adalah bentuk journal voucher yang digunakan oleh PT MNI Entertainment Jakarta Pusat.

Berikut ini sejumlah pencatatan pengeluaran petty cash atau kas kecil pada PT MNI Entertainment Jakarta Pusat selama 3 (tiga) bulan yaitu bulan Januari, Februari dan Maret 2019.

1. Periode Januari 2019

1. Pada saat pembentukan dana kas kecil

Dana kas kecil dibentuk berdasarkan jumlah pengeluaran yang telah dilakukan sebelumnya. kemudian cek akan dibuat dan dicairkan sebesar jumlah pengeluaran tersebut. jurnal pembentukan dana kas kecil ini dibuat dengan cara mendebit kas kecil dan mengkredit akun kas di bank. Pembentukan dana kas kecil periode Januari 2019 adalah sebagai berikut.
Tabel 1. Pembentukan dana kas kecil periode Januari 2019

\begin{tabular}{|l|l|c|c|c|c|c|}
\hline \multicolumn{2}{|c|}{ ACCOUNT } & ADD & \multirow{2}{*}{ CCY } & \multirow{2}{*}{ KURS } & \multicolumn{2}{|c|}{ ACTUALCCY } \\
\cline { 5 - 7 } & REF & & & DEBET & KREDIT \\
\hline & Pettycash & & $\mathbb{D R}$ & 1.00 & 9.000 .000 & \\
\hline & Kas bank & & $\mathbb{D R}$ & 1.00 & & 9.000 .000 \\
\hline & Saldo & & $\mathbb{D R}$ & 1.00 & \multicolumn{2}{|c}{9.000 .000} \\
\hline
\end{tabular}

Sumber: Finence PT MNI Entertainment (2019)

2. Pada saat pengisian kembali

Seluruh kas kecil beserta dokumen pendukungnya akan diajukan ke bagian finance SPV untuk selanjutnya diperiksa pengeluarannya.setelah pemeriksaan selesai, kasir akan melakukan pengisian kembali dana kas kecil.

Berikut adalah pengisian kembali kas kecil pada periode Januari 2019.

\section{Tabel 2. Pengisisan Kembali Kas Kecil Periode Januari 2019}

\begin{tabular}{|c|c|c|c|}
\hline No & No. Bukti & Keterangan & Kredit \\
\hline 1 & PC0119,0001 & Pembayaran entertaint klien (CV Tika Utama) & 157.000 \\
\hline 2 & PCO119,0002 & Pembayaran BPJS TK $(J F K)$ & 553.875 \\
\hline 3 & PCO119,0003 & Pembayaran ekses klaim (C/11/18000693 dan C/11/180004517) & 197.000 \\
\hline 4 & PCO119,0004 & Pembayaran pembelian majalah competitor & 170.000 \\
\hline 5 & PCO119,0005 & Pembayaran pengirman langganan majalah & 48.000 \\
\hline 6 & PC0119,0006 & $\begin{array}{l}\text { Pembayaran entertaint (MS Glow Beauty,Dream Crise,Sweet } \\
\text { Escape,Optik) }\end{array}$ & 955.303 \\
\hline 7 & PCO119,0007 & Pembayaran pembelian materai (stok fimance,stok HRD) & 450.000 \\
\hline 8 & PCO119:0008 & Pembayaran pengiriman dokumen (konfirmasi bank, redaksi) & 27.000 \\
\hline 9 & PC0119,0009 & Pembayaran pengiriman majalah, bandung & 22.000 \\
\hline 10 & PCO119,0010 & Pembayaran pembelian kertas $\mathrm{AA}$ dan $\mathrm{FA}$ & 263.000 \\
\hline 11 & PCO119,0011 & Pembayaran kelurangan pph 23 maret 2018 (sisipan gramedia) & 7.277 \\
\hline 12 & PC0119/0012 & Pembayaran service printer (finance) & 375.000 \\
\hline 13 & PCO119,0013 & Pembayaran refill toner (printer HRD) & 150.000 \\
\hline 14 & PCO119:0014 & Pembayaran meals photographer (fashion) & 300.000 \\
\hline 15 & PCO119,0015 & Pembayaran tp kantor & 513.500 \\
\hline 16 & PC0119/0016 & Pembayaran pembelian peralatan dapur & 95.000 \\
\hline 17 & PCO119/0017 & Pembelian aqua gelas (ruang meetimg) & 31.000 \\
\hline 18 & PCO119,0018 & Pembayaran ID Card (VMS-1901V0009) & 55.000 \\
\hline 19 & PCO119:0019 & Pembayaran belanja bulanan & 262.000 \\
\hline 20 & PCO119,0020 & Pembayaran laundry (baju fashion) & 365.000 \\
\hline 21 & PCO119,0021 & Rembursement operasional GA & 2.201 .650 \\
\hline & & & 7.041 .605 \\
\hline
\end{tabular}

Sumber: Finance PT MNI Entertainment (2019)

3. Periode Januari 2019 (berikutnya) dan Februari 2019

1. Pembentukan dana kas kecil

Pada pertengahan bulan Januari 2019 dilakukan pengisian kembali kas kecil, jumlah pengisian kembali dana tersebut yaitu sebesar Rp 7.041.605,-.

Berikut adalah pembentukan dana kas kecil periode Januari 2019 (berikutnya). 
Tabel 3. Pembentukan dana kas kecil periode Januari 2019 (berikutnya)

\begin{tabular}{|l|l|c|c|c|c|c|}
\hline \multicolumn{2}{|c|}{ ACCOUNT } & \multirow{2}{*}{$\begin{array}{l}\text { ADD } \\
\text { REF }\end{array}$} & \multirow{2}{*}{ CCY } & \multirow{2}{*}{ KURS } & \multicolumn{2}{|c|}{ ACTUAL CCY } \\
\cline { 5 - 7 } & & & & DEBET & KREDIT \\
\hline & Petty cash & & IDR & 1.00 & 7.041 .605 & \\
\hline & Cash on hand & & $\mathbb{I D R}$ & 1.00 & 1.958 .395 & \\
\hline & Kas bank & & IDR & 1.00 & & 7.041 .605 \\
\hline & Saldo & & IDR & 1.00 & \multicolumn{2}{|c|}{9.000 .000} \\
\hline
\end{tabular}

Sumber: Finance PT Mni Entertainment (2019)

2. Pengisian kembali dana kas kecil

Dikarenakan pengeluaran petty cash pada periode Januari 2019 (berikutnya) jumlahnya sedikit, maka pihak kasir menggabungkan petty cash pada periode Januari 2019 (berikutnya) dengan periode Februari 2019, sehingga pada periode Januari 2019 (berikutnya) tidak melakukan pengisian kembali, dan kasir melakukan penggisian kembali pada periode Februari 2019.

Berikut pengisian kembali petty cash periode Januari 2019 (berikutnya) dan periode Februari 2019.

Tabel 4. Pengisian kembali dana kas kecil periode Januari 2019 (berikutnya) dan periode Februari 2019

\begin{tabular}{|c|c|c|c|}
\hline No & No. Bukti & Keterangan & Kredit \\
\hline 1 & PC 0119/0022 & Pengembalian kelebihan reimburs petty cash & 496.990 \\
\hline 2 & PC 0119/0023 & Pembayaran penginiman dokumen (redaksi,finance) & 54.000 \\
\hline 3 & PC 0119/0024 & Pembayaran entertaint (frank n'co, hans management) & 478.093 \\
\hline 4 & PC 0119/0025 & Pembayaran meals photographer (fashion) & 180.000 \\
\hline 5 & PC 0119/0026 & Pembayaran penguriman majalah, makasar & 150.000 \\
\hline 6 & PC 0119/0027 & Pembelian trigger ott (photographv) & 280.000 \\
\hline 7 & PC 0119/0028 & Reimburse transport dan GRAB & 2.347 .734 \\
\hline 8 & PC 0219/0001 & Pembayaran pembelian majalah kompetitor & 165.000 \\
\hline 9 & PC 0219/0002 & Pembayaran penginman majalah (langganan $\mathrm{HE}$ dan JFK) & 47.000 \\
\hline 10 & PC 0219/0003 & Pembayaran entertaint (Heidi generale) & 169.500 \\
\hline 11 & PC 0219/0004 & Pembayaran penginman majalah (bukti tavang nava park) & 27.000 \\
\hline 12 & PC 0219/0005 & Pembelian makan siang (pembersihan barang pindahan) & 80.000 \\
\hline 13 & PC 0219/0006 & Pembayaran ekses klaim (C/12/18003342) & 70.000 \\
\hline \multirow[t]{2}{*}{14} & PC 0219/0007 & Reimbursement operasional GA & 2.692 .780 \\
\hline & & & 7.238 .097 \\
\hline
\end{tabular}

Sumber : Finance PT Mni Entertainment (2019)

3. Periode Februari 2019 (berikutnya)

1. Pembentukan dana kas kecil

Pada pertengahan bulan Februari 2019 dilakukan pengisian kembali dana kas kecil, jumlah pengisian kembali dana tersebut yaitu sebesar Rp 7.238.097,- .

Berikut adalah pembentukan dana kas kecil periode Februari 2019 (berikutnya).
Tabel 5. Pembentukan dana kas kecil periode Februari 2019

\begin{tabular}{|l|l|c|c|c|c|c|}
\hline \multicolumn{2}{|c|}{ ACCOUNT } & \multirow{2}{*}{$\begin{array}{l}\text { ADD } \\
\text { REF }\end{array}$} & \multirow{2}{*}{ CCY } & \multirow{2}{*}{ KURS } & \multicolumn{2}{|c|}{ ACTCAL CCY } \\
\cline { 5 - 7 } & & & DEBET & KREDIT \\
\hline & Petty cash & & IDR & 1.00 & 7.238 .097 & \\
\hline & Cash on hand & & IDR & 1.00 & 1.761 .903 & \\
\hline & Kas bank & & IDR & 1.00 & & 7.238 .097 \\
\hline & Saldo & & IDR & 1.00 & \multicolumn{2}{|c}{9.000 .000} \\
\hline
\end{tabular}

Sumber: Finance PT Mni Entertainment (2019)

2. Pengisian kembali dana kas kecil Berikut pengisian kembali petty cash yang dilakukan pada periode Februari 2019 (berikutnya).

Tabel 6. Pengisisan Kembali Dana Kas Kecil Periode Februari 2019 (Selanjutnya

\begin{tabular}{|c|c|l|c|}
\hline No & No. Bukti & \multicolumn{1}{|c|}{ Keterangan } & Kredit \\
\hline 1 & PC 0219/0008 & Pembayaran Entertain (havas, optic melawai,optic seis,mnc & 877.803 \\
& & land) & \\
2 & PC 0219/0009 & Pembayaran pembelian beterai fhotograf \& belanja pantry & 150.000 \\
3 & PC 0219/0010 & Pembayaran meals fashion & 180.000 \\
4 & PC 0219/0011 & Pembayaran laundry gaun miss Indo. 2019 & 210.000 \\
5 & PC 0219/0012 & Pembayaran jasa pengiriman (PEX's) & 309.680 \\
6 & PC 0219/0013 & Pembayaran pembelian materai (stock finance) & 300.000 \\
7 & PC 0219/0014 & Pembayaran SPJ 15-16 feb 2019, yogyakarta, valentine concert & 260.000 \\
8 & PC 0219/0015 & Pembayaran tlp kantor Jan 2019 & 506.685 \\
9 & PC 0219/0016 & Pembayaran pengiriman dokumen & 112.000 \\
10 & PC 0219/0017 & Reimbursment operasional GA & 2.381 .436 \\
11 & PC 0219/0018 & Reimbursement operasional GA & 1.428 .600 \\
& & & \\
& & & 6.716 .204 \\
\hline
\end{tabular}

. Sumber: Finance PT MNI Entertainmen (2019)

3. Periode Maret 2019

1. Pembentukan dana kas kecil

Pada awal bulan Maret 2019 dilakukan pengisian kembali dana kas kecil, jumlah pengisian kembali dana tersebut yaitu sebesar Rp 6.716.204,- .

Berikut adalah pembentukan dana kas kecil periode Maret 2019.

Tabel 7. Pembentukan Dana Kas Kecil Periode Maret 2019

\begin{tabular}{|l|l|l|l|l|l|l|}
\hline \multicolumn{2}{|c|}{ ACCOUNT } & ADD & \multirow{2}{*}{ CCY } & \multirow{2}{*}{ KURS } & \multicolumn{2}{|c|}{ ACTUAL CCY } \\
\cline { 5 - 7 } & REF & & & DEBET & KREDIT \\
\hline & Petty cash & & IDR & 1.00 & 6.716 .204 & \\
\hline & Cash on hand & & IDR & 1.00 & 2.283 .796 & \\
\hline & Kas bank & & DR & 1.00 & & 6.716 .204 \\
\hline & Saldo & & DRR & 1.00 & \multicolumn{2}{|c|}{9.000 .000} \\
\hline
\end{tabular}

Sumber: Finance PT MNI Entertainment (2019) 
2. Pengisian kembali dana kas kecil

Berikut pengisian kembali petty cash yang dilakukan pada periode Maret 2019.

\section{Tabel 8. Pengisian Kembali Dana Kas Kecil Periode Maret 2019}

\begin{tabular}{|c|c|c|c|}
\hline$\overline{N_{0}}$ & No. Bukti & Keterangan & Kredit \\
\hline 1 & $\mathrm{PC} 0319,0001$ & Pembayaran laundry jacket fashion & 70.000 \\
\hline 2 & PC 0319,0002 & $\begin{array}{l}\text { Pembayaran ekses klaim (No. Batch 131302) (No. Wlaim } \\
19001945 \text { ) }\end{array}$ & 50.000 \\
\hline 3 & PC 0319,0003 & Pembayaran belanja bulanan pantry & 248.500 \\
\hline 4 & PC 0319,0004 & Pembayaran pengirman langganan majalah & 47.000 \\
\hline 5 & PC 0319,0005 & Pembayaran klaim asuransi mobil (B 1103 PZE) & 300.000 \\
\hline 6 & PC 0319,0006 & Pembavaran pengirman langganan majalah & 110.000 \\
\hline 7 & PC 0319,0007 & Pembayaran th indosat feb 2019 & 359.828 \\
\hline 8 & PC 0319,0008 & Pembayaran pembelian majalah kompetitor & 195.000 \\
\hline 9 & PC 0319,0009 & Pembayaran serifikat elektronik JFK & 165.467 \\
\hline 10 & PC 0319,0010 & Pembayaran tp kantor & 519.622 \\
\hline 11 & PC 0319/0011 & Pembelian kertas F4 & 270.000 \\
\hline 12 & PC 0319,0012 & Rembursement operasional GA & 2.999 .330 \\
\hline \multirow[t]{2}{*}{13} & PC 0319,0013 & Rembursement operasional GA & 1.859 .500 \\
\hline & & & 7.194 .247 \\
\hline
\end{tabular}

Sumber: Finance PT MNI Entertainment (2019)

3. Periode Maret 2019 (berikutnya)

1. Pembentukan dana kas kecil

Pada pertengahan bulan Maret 2019 dilakukan pengisian kembali dana kas kecil, jumlah pengisian kembali dana tersebut yaitu sebesar Rp 7.194.247,- .

Berikut adalah pembentukan dana kas kecil periode Maret 2019.

Tabel 9. Pembentuka Dana Kas Kecil Periode Maret 2019 ( berikutnya)

\begin{tabular}{|c|c|c|c|c|c|}
\hline \multirow{2}{*}{ AccotNT } & \multirow{2}{*}{$\begin{array}{l}A D D \\
\text { REF }\end{array}$} & \multirow{2}{*}{$\mathrm{CCY}$} & \multirow{2}{*}{ KURS } & \multicolumn{2}{|c|}{ ACTUALCCY } \\
\hline & & & & DEBET & KREDIT \\
\hline Petty cash & & $\mathbb{D} \mathbb{R}$ & 1.00 & 7.194 .247 & \\
\hline Cashonhand & & $\mathbb{D} R$ & 1.00 & 1.8057 .753 & \\
\hline Kas bank & & $\mathbb{D} R$ & 1.00 & & 7.194 .247 \\
\hline Saldo & & $\mathbb{D} R$ & 1.00 & & \\
\hline
\end{tabular}

Sumber: Finance PT MNI Entertainment (2019)

2. Pengisian kembali dana kas kecil Berikut pengisian kembali petty cash yang dilakukan pada periode Maret 2019 (berikutnya).
Tabel 10. Pengisisan kembali dana kas periode Maret 2019 (berikutnya)

\begin{tabular}{|c|c|c|c|}
\hline $\mathrm{N}_{0}$ & No. Bulkti & Keterangan & Kredit \\
\hline 1 & PC 03190001 & $\begin{array}{l}\text { Entertaimment (paashion,BRLHavas, adelle jewellery,mitra } \\
\text { menunggal,central mega kencara, charriol Watch,aston } \\
\text { kartika,Miss IIMS) }\end{array}$ & 1.944 .732 \\
\hline 2 & PC 0319,0002 & Pembayaran meals fashion & 80.000 \\
\hline 3 & PC 03190003 & Pembayaran pengirman majalah & 18.000 \\
\hline 4 & PC 03190004 & Pembayaran pengiriman dokumen (SPK) & 24.000 \\
\hline 5 & PC 03190005 & Pembayaran entertaint klien (CV. Tika Utama) & 157.000 \\
\hline 6 & PC 0319,0006 & Pemberian tanda sukacita karyawan & 400.000 \\
\hline 7 & PC 03190007 & Pembayaran pembelian materai (stock fimance) & 300.000 \\
\hline 8 & PC 0319,0008 & Pembayaran belanja bulanan & 300.000 \\
\hline 9 & PC 0319,0009 & Reimbursement operasional GA & 2.642 .425 \\
\hline 10 & PC 0319:0010 & Reimbursement operasional GA & 1.821 .501 \\
\hline 11 & PC 0319,0023 & Pengembalian kelebihan rembursement pettycash & 339.990 \\
\hline & & & 7.347 .668 \\
\hline
\end{tabular}

Sumber: Finance PT MNI Entertainmet (2019)

\section{KESIMPULAN}

Dari hasil penelitian penulis mengenai analisis pelaksanaan pencatatan petty cash pada PT MNI Etertainment Jakarta Pusat, dapat ditarik kesimpulan sebagai berikut:

Pengelolaan petty cash yang diterapkan oleh PT MNI Entertainment Jakarta Pusat yaitu dengan menggunakan metode atau sistem dana tetap (imprest system), yang mana dalam metode ini penetapan dana kas kecil selalu tetap dalam periodenya. PT MNI Entertainment menetapkan dana kas kecil sejumlah Rp 9.000.000,- untuk setiap periodenya. Dalam pengisian kembali petty cash dilakukan setiap akhir periode atau pada saat jumlah dana petty cash telah menipis. Pengisian dana dilakukan dengan menggunakan cek sejumlah petty cash yang telah dikeluarkan sehingga dana kas kecil tetap dalam jumlah semula.

Dalam prosedur pencatatan petty cash, PT MNI Entertainment melibatkan beberapa pihak yang terkait dalam kegiatan operasionalnya, pihak yang terkait dalam pelaksanaan pencatatan petty cash diantaranya yaitu user atau pihak yang mengajukan pembayaran petty cash, pihak kasir sebagai pelaksanaanya, finance SPV sebagai pihak pemeriksaan petty cash dan juga bank sebagai pencairan dana petty cashnya.

Dalam pelaksanaan pencatatan petty cash $\mathrm{PT}$ MNI Entertainment haya melibatkan 2 pihak yaitu bagian kasir dan finance SPV, sehingga kasir melakukan doubel job. Perusahaan sebaiknya menempatkan pegawai untuk melakukan pempostingan petty cash kedalam journal voucher. Sehingga dalam pelaksanaan pencatatan petty cash bisa lebih teliti lagi dan tidak mengalami kesalahaan dalam penamaannya 


\section{REFERENSI}

Arizona, N. D., Yulia, \& Saputro, R. (2018). Aplikasi Pengolahan Data Penerimaan Dan Pengeluaran Kas Pada Smk Cahaya Bangsa Kabupaten Kubu Raya. PILAR Nusa Mandiri, 14(2), 253260 .

Atika, L., \& Pusung, R. J. (2018). Ipteks Pengelolaan Kas Kecil ( Petty Cash ) Pada Pt. Pln (Persero) Unit Induk Pembangunan Sulawesi Bagian Utara. Ipteks Akutansi Bagi Masyarakat, 2(2), 370-373.

Hidayati, N. (2019). Pengembangan Sistem Informasi Pengeluaran Kas Atas Pengadaan Proyek
Dengan Menggunakan Metode Waterfall. Paradigma, XXI(1), 61-68.

Wasiyanti, S. (2015). Sistem Informasi Arus Kaas Studi Kasus Pada Pt Adhinata Karya Marmer. Perspektif, XIII(2), 160-170.

Wati, E. F., \& Kusumo, A. A. (2016). Penerapan Metode Unified Modeling Language ( UML ) Berbasis Desktop Pada Sistem Pengolahan Kas Kecil Studi Kasus Pada PT Indo Mada Yasa Tangerang. Informatika, 5(1), 24-36. 